\title{
BERBAGAI JENIS DAN KONSENTRASI REPELLENT ALAMI TERHADAP LAMA WAKTU EFEK REPELLENT DAYA HINGGAP LALAT PADA IKAN ASIN DI KUB MINA MANDIRI CILACAP KABUPATEN CILACAP TAHUN 2016
}

\author{
Erik Budi Santoso $^{1)}$, Arif Widyanto ${ }^{2)}$, Budi Triyantoro ${ }^{3)}$ \\ Jurusan Kesehatan Lingkungan, Politeknik Kesehatan Kemenkes Semarang \\ Jl. Raya Baturaden KM 12 Purwokerto, Indonesia
}

\begin{abstract}
Abstrak
Tahap pengeringan ikan asin memiliki potensi risiko pertumbuhan mikroorganisme akibat investasi lalat, sehingga dapat menyebabkan kerusakan fisik dan juga menjadi perantara bagi kontaminasi bakteri pembusuk, patogen serta pembentuk racun dan dapat menjadi transmisi penyebab penyakit bagi konsumen. Kencur, Serai Wangi dan Kunyit dapat digunakan sebagai daya tolak lalat dan aman digunakan pada bahan makanan. Metode penelitian menggunakan pra eksperimental dengan rancangan the static group comparison design. Hasil penelitian menunjukkan daya proteksi dari ekstrak Kencur konsentrasi 3\% (64.22\%), konsentrasi 6\% (73.35\%), konsentrasi 12\% (62.67\%), dan konsentrasi 24\% (70.11\%). Ekstrak Serai Wangi konsentrasi 3\% (48.59\%), konsentrasi 6\% (61.78\%), konsentrasi 12\% (50.12\%), dan konsentrasi 24\% (56.51\%) dan ekstrak Kunyit konsentrasi 3\% (65.35\%), konsentrasi 6\% (44.09\%), konsentrasi 12\% (50.12\%), dan konsentrasi 24\% (56.51\%) terhadap hinggapnya lalat dan rata-rata efek repellent mengalami fluktuasi dari jam ke 1-6 dan perbedaan yang signifikan karena nilai sig $p<\alpha 0,05$ yaitu $0,000-0,01<0,05$ serta konsentrasi tidak berpengaruh pada nilai sig $\mathrm{p}>\alpha 0,05$. Repellent dikatakan efektif apabila hingga jam ke-6 daya proteksi masih diatas $90 \%$. Kesimpulan penelitian adalah terdapat perbedaan daya proteksi, tetapi tidak ada yang efektif untuk menolak lalat karena daya proteksi ekstrak Kencur, Serai Wangi dan Kunyit tidak ada yang mencapai 90\% sampai jam ke- 6 .
\end{abstract}

Kata Kunci : Ekstrak Kencur,Serai Wangi dan Kunyit-Ikan Asin-Lalat

\begin{abstract}
[Various Types And Concentration Of Natural Repellent Towards Repellent Effect Duration Of Flies Landing On Salted Fish In Kub Mina Mandiri Cilacap, Cilacap Regency Year 2016] Drying stage of salted fish has a potential risk on growth of microorganism caused by flies investation so that it can cause physical damage and a mediator for contaminating decomposition bacteria, pathogen and poison, and can also be transmission od disease for consumers. Natural pesticide usages, such as: Greater galingale, Lemongrass and Turmeric can be used for flies repellent and safe for food. The method used in this research is pra-experimental with the static group comparison design. The result shows that protection capability from Greater galingale extract in dosage 3\% (64.22\%), dosage 6\% (73.35\%), dosage 12\% (62.67\%), and dosage 24\% (70.11\%). Lemongrass extract in dosage $3 \%(48.59 \%)$, dosage 6\% (61.78\%), dosage 12\% (50.12\%), and dosage 24\% (56.51\%). And Turmeric extract in dosage 3\% (65.35\%), dosage 6\% (44.09\%), dosage 12\% (50.12\%), and dosage 24\% (56.51\%)toward flies landing and the average effect repellent experienced fluctuations of hours to 1-6and there was a significant difference because the value of sig $p<\alpha 0,05$ it was $0,000-0,01<0,05$ and concentration did not influence the value of s sig $p>\alpha 0,05$. Repellentwas effective if until the sixth hours the protection capability was above $90 \%$.The conclusion of this research is there was a difference but nothing was effective to prevent flies because the protection capability of Greater galingale, Lemongrass, and Turmeric extracts none of them were getting to 90\% until the sixth hours.
\end{abstract}

Key words $\quad$ : Greater galingale, Lemongrass, and Turmeric extracts- Salted Fish-Flies

\section{PENDAHULUAN}

Undang-undang Republik Indonesia Nomor 18 pasal 1 Tahun 2012, menyatakan bahwa keamanan pangan merupakan kondisi dan upaya yang diperlukan untuk mencegah pangan dari kemungkinan cemaran biologis, kimia, dan benda lain yang dapat mengganggu, merugikan, dan membahayakan kesehatan manusia serta tidak

1) Email : Abbeepic@yahoo.com

2) Email : Arifwidyanto74@yahoo.com

3) Email : Mutshabira@yahoo.com bertentangan dengan agama, keyakinan, dan budaya masyarakat sehingga aman untuk dikonsumsi.

Ikan merupakan salah satu sumber bahan pangan yang harus dijaga keamanannya karena kegunaan dalam memenuhi kebutuhan akan zat gizi protein. Ikan juga diakui sebagai functional food yang mempunyai arti penting bagi kesehatan karena mengandung asam lemak tidak jenuh berantai 
panjang, vitamin, serta makro dan mikro mineral (Heruwati, 2002).

Tahap penjemuran atau pengeringan merupakan salah satu proses penting yang dilakukan dalam pengolahan ikan asin (Afrianto, 1991). Pada proses atau tahap pengeringan ikan asin memiliki potensi risiko pertumbuhan mikroorganisme akibat infestasi lalat. Penjemuran ikan asin yang dilakukan di tempat udara dengan memanfaatkan sinar matahari, yang dapat mendatangkan lalat, yakni lalat rumah (Musca domestica) dan lalat hijau (Chrysomya megacephala). Lalat dapat menyebabkan kerusakan fisik dan juga menjadi perantara bagi kontaminasi bakteri pembusuk, patogen serta pembentuk racun, seperti : Acinetobacter, Staphylococcus, dan Vibrionaceae serta dapat menjadi transmisi penyebab penyakit, seperti : Shigella, E coli, Salmonella spp, Vibrio cholera, Helicobacteri pylori, H5N1, Virus Sinusitis dan Virus Hepatitis. Hasil pengamatan menunjukkan bahwa satu ekor lalat dapat membawa sekitar 102103 bakteri pada musim kemarau dan antara 108-109 pada musim hujan. Penanggulangan kerusakan akibat lalat dan kontaminasi dari lalat selama penjemuran pengolah ikan asin perlu dilakukan untuk menjaga keamanan pangan (Heruwati, 2002).

Insektisida sintesis sering kali digunakan untuk mengurangi dan menanggulangi kerusakan akibat lalat dan kontaminasi dari lalat selama penjemuran, pengolah ikan asin yang disemprot secara langsung pada produk ikan (Ariyani, dkk., 2007). Insektisida yang berasal dari alam dan penggunaannya aman bagi lingkungan maupun masyarakat perlu dikembangkan untuk mengurangi penggunaan insektisida sintetik. Insektisida nabati memiliki susunan molekul yang mudah terurai menjadi senyawa yang tidak membahayakan. Tanaman yang tergolong ke dalam tanaman aromatik, seperti : Serai Wangi, kayu putih, Kencur, geranium, zodia, Kunyit, dan lainnya diyakini mempunyai khasiat mengusir lalat (Kardinan, 2007). Senyawa yang terkandung dalam tumbuhan dan berfungsi sebagai insektisida diantaranya adalah golongan Sianida, Saponin, Tannin, Flavanoid, Alkaloid, Steroid dan minyak atsiri (Naria, 2005).

Penelitian yang dilakukan oleh Rosnawati (1998) diperoleh bahwa ekstrak Kencur lebih efektif mencegah datangnya serangga pada pengolahan ikan asin dibanding insektisida sintetis jenis pirimiphos methyl. Pirimiphos methyl lebih efektif dibandingkan ekstrak Kencur sebagai racun kontak. Pengujian karakteristik mutu ikan asin (Kadar air, kadar nitrogen. kadar lemak dan total mikroba) menunjukkan bahwa kadar air ikan asin 38,33 42,51 persen masih berada dalam kisaran standar kadar air maksimum ikan asin menurut SP1(35 - 45 \%). Pemberian ekstrak Kencur tidak berpengaruh nyata baik pada kadar Nitrogen, kadar lemak, maupun total mikroba.
Penelitian yang dilakukan oleh Fardaniyah (2007) untuk mengetahui pengaruh minyak Serai Wangi (Cymbopogon nardus L) sebagai alternatif insektisida nabati terhadap infestasi lalat hijau (Chrysomya megacephala) pada ikan segar.

Penelitian ini dilakukan dengan memasukkan ekor ikan mas segar yang masing-masing dilumuri minyak Serai Wangi dengan konsentrasi bertingkat, dimulai dari $0 \%$ (kontrol), 2,5\%, 5\%, 10\%, 20\%, hingga $40 \%$, ke dalam kandang biakan lalat $C$. megacephala. Hasil penelitian menunjukkan bahwa terjadi penurunan daya hinggap lalat dimulai dari konsentrasi 2,5\%, dan penurunan jumlah larva yang signifikan pada ikan mas yang dilumuri minyak Serai Wangi mulai dari konsentrasi 2,5\%, hingga $40 \%$ dibandingkan terhadap kontrol.

Penelitian yang dilakukan oleh Warnaini (2007) untuk mengetahui efek antibakteri (konsentrasi daya hambat) ekstrak Kunyit terhadap pertumbuhan bakteri Bacillus sp. dan Shigella dysentriae. Penelitian ini merupakan penelitian ekperimental laboratorik menggunakan metode disc diffusion untuk melihat aktivitas antibakteri Kunyit terhadap pertumbuhan bakteri Bacillus sp. dan Shigella dysentriae. Ekstrak Kunyit yang digunakan memiliki konsentrasi 15\% , 30\%, 50\%, 75\%, 100\%. Kontrol positif digunakan Amoksilin dan Chlorampheniocol. Hasil pengamatan menunjukkan ekstrak Kunyit memiliki daya hambat terhadap pertumbuhan bakteri Bacillus sp dan Shigella dysentriae.

Koperasi Unit Bersama (KUB) Mina Mandiri merupakan home industry yang dirintis oleh ibu Saginah dan suami bapak Suyono sejak tahun 1975, pada awalnya mereka hanya berjualan ikan asin keliling di daerahnya. Kemudian mereka mendapat bantuan modal dari Pertamina untuk mengembangkan usaha yang dirintisnya. Home industry tersebut berada di Jl. Bakung RT 06/05 Sidakaya, Cilacap. KUB Mina Mandiri yang berdekatan dengan sungai yang tercemar serta berada diperkampungan kumuh padat penduduk. Menurut hasil pengukuran kepadatan lalat yang menunjukan bahwa kepadatan lalat > 20 ekor/ grill yang artinya populasi sangat padat, maka perlu dilakukan pengamatan dan pengendalian, dengan hasil 26 ekor/ grill.

Berdasarkan uraian diatas, maka penulis tertarik untuk membuat skripsi dengan judul "Berbagai Berbagai Jenis dan Konsentrasi Repellent Alami terhadap Lama Waktu Efek Repellent Daya Hinggap Lalat pada Ikan Asin di KUB Mina Mandiri Cilacap, Kabupaten Cilacap Tahun 2016”.

\section{METODE PENELITIAN}

Variabel bebas yaitu jenis repellent, konsentrasi repellent dan lama waktu kontak. Variabel terikat yaitu Efek repellent. Variabel penganggu yaitu fisik ikan asin dan bau ikan asin. 
Penelitian ini termasuk dalam penelitian Pra Eksperimen (Pre Experimental) dengan dengan desain The Static Group Comparison Design.

Populasi dalam penelitian ini adalah seluruh ikan asin yang di jemur di Koperasi Unit Bersama (KUB) Mina Mandiri Cilacap, Kabupaten Cilacap. Sampel dalam penelitian adalah ikan asin sebelah (lendra) yang berukuran $\pm 10 \mathrm{~cm}$ dengan sampel 36 ikan asin mendapat perlakuan dan 12 ikan asin sebagai kontrol di penjemuran ikan asin, Koperasi Unit Bersama (KUB) Mina Mandiri Cilacap, Kabupaten Cilacap.

Metode pengumpulan data pada data umum yang diperlukan dalam penelitian adalah profil umum tempat dilaksanakannya penelitian, yaitu KUB Mina Mandiri Cilacap dan suhu, dan kelembaban udara tempat penjemuran ikan asin. Dan data khusus dalam penelitian ini adalah efek repellent terhadap jumlah lalat yang hinggap pada ikan uji maupun ikan asin kontrol.

Analisis yang digunakan yaitu Analisis univariat yang dilakukan terhadap tiap variabel dari hasil penelitian. Analisis univariat menggunakan tabel atau gambar uji perlakuan repellent ekstrak Kencur, Serai Wangi dan Kunyit. Sedangkan data yang berskala ratio, meliputi : mean, median, standar deviasi, minimum, maksimum, dan jumlah. Analisis bivariat digunakan untuk menguji digunakan yaitu Anova Factorial, karena perlakuan pada sabyek lebih dari satu dan masing-masing perlakuan mempunyai replikasi dan analisis data menggunakan software stastistik (Santjaka, A., 2008). Analisis multivariate dalam satu atau lebih hubungan. Analisis ini berhubungan dengan semua teknik statistik yang secara simultan menganalisis sejumlah pengukuran pada individu atau objek (Singgih Santoso, 2010).

\section{HASIL DAN PEMBAHASAN}

Lama Waktu Daya Proteksi Berbagai Jenis dan Dosis Ekstrak Kencur (Kaempferia galanga L.), Serai Wangi (Cymbopogon nardus L.) dan Kunyit (Curcuma longa L.) pada Ikan Asin

Pengukuran suhu dan kelembaban udara pada lokasi penelitian bertujuan untuk mengetahui suhu pada saat perlakuan, mulai hari pertama penelitian dilakukan sampai dengan hari ke dua. Suhu udara di lokasi penelitian diukur tiap jam, mulai dari pukul 10.00-13.00 WIB pada tanggal 17 Mei 2016. Berdasarkan pengukuran suhu udara pada lokasi penelitian berkisar antara $31-32{ }^{\circ} \mathrm{C}$ dengan rata-rata $31,16{ }^{\circ} \mathrm{C}$, dan pengukuran kelembaban udara pada lokasi penelitian berkisar antara 61\%-64\% dengan rata-rata 57,15\%, jadi masih dalam batas suhu dan kelembaban udara perkembangbiakan lalat menurut Depkes RI (1995) masih sesuai untuk perkembangan hidup lalat.

Menurut Departemen Pertanian dalam Metode Standar Pengujian Efikasi Pestisida tahun 1995 yaitu repellent dianggap efektif apabila hingga jam ke-6 daya proteksinya masih diatas $90 \%$, tetapi ada dosis ekstrak Kencur pada jam ke 5 mencapai rata-rata 97,222 tapi pada jam ke 6 mengalami penurunan menjadi 62,9870. Rata - rata daya proteksi masing masing jenis dan dosis repellent hingga jam ke-6 ekstrak Kencur dosis 3\% daya proteksinya sebesar $64,2222 \%$, dosis $6 \%$ sebesar $73,3532 \%$, serta dosis $12 \%$ daya proteksinya sebesar $62,6777 \%$ dan dosis 24\% sebesar 70,1131\%. Ekstrak Serai Wangi dosis $3 \%$ daya proteksinya sebesar $48,75 \%$, dosis $6 \%$ sebesar $61,7882 \%$, serta dosis $12 \%$ daya proteksinya sebesar 56,5194\% dan dosis 24\% sebesar 48,5981\%. Ekstrak Kunyit dosis 3\% daya proteksinya sebesar $65,3517 \%$, dosis $6 \%$ sebesar $44,0940 \%$, serta dosis $12 \%$ daya proteksinya sebesar $50,1235 \%$ dan dosis 24\% sebesar 56,5194\%. Berdasarkan hasil tabel uji deskiptif statistik menunjukkan bahwa ada pengaruh efek repellent dalam menghambat daya hinggap lalat pada ikan asin, tetapi pada tiap jenis dan konsentrasi ekstrak dari jam ke 1 sampai dengan jam ke 6 daya proteksi mengalami fluktuasi yang signifikan.

Penelitian yang dilakukan oleh Rosnawati (1998) diperoleh bahwa ekstrak Kencur lebih efektif mencegah datangnya serangga pada pengolahan ikan asin dibanding insektisida sintetis jenis pirimiphos methyl. Pirimiphos methyl lebih efektif dibandingkan ekstrak Kencur sebagai racun kontak. Pengujian karakteristik mutu ikan asin (Kadar air, kadar nitrogen. kadar lemak dan total mikroba) menunjukkan bahwa kadar air ikan asin 38,33 42,51 persen masih berada dalam kisaran standar kadar air maksimum ikan asin menurut SP1(35 - 45 \%). Pemberian ekstrak Kencur tidak berpengaruh nyata baik pada kadar Nitrogen, kadar lemak, maupun total mikroba.

Penelitian yang dilakukan oleh Fardaniyah (2007) untuk mengetahui pengaruh minyak Serai Wangi (Cymbopogon nardus L) sebagai alternatif insektisida nabati terhadap infestasi lalat hijau (Chrysomya megacephala) pada ikan segar. Penelitian ini dilakukan dengan memasukkan ekor ikan mas segar yang masing-masing dilumuri minyak Serai Wangi dengan konsentrasi bertingkat, dimulai dari $0 \%$ (kontrol), 2,5\%, 5\%, 10\%, 20\%, hingga 40\%, ke dalam kandang biakan lalat C. megacephala. Hasil penelitian menunjukkan bahwa terjadi penurunan daya hinggap lalat dimulai dari konsentrasi 2,5\%, dan penurunan jumlah larva yang signifikan pada ikan mas yang dilumuri minyak Serai Wangi mulai dari konsentrasi 2,5\%, hingga 40\% dibandingkan terhadap kontrol.

Penelitian yang dilakukan oleh Warnaini (2007) untuk mengetahui efek antibakteri (konsentrasi daya hambat) ekstrak Kunyit terhadap pertumbuhan bakteri Bacillus sp. dan Shigella dysentriae. Penelitian ini merupakan penelitian ekperimental laboratorik menggunakan metode disc diffusion untuk melihat aktivitas antibakteri Kunyit terhadap pertumbuhan bakteri Bacillus sp. dan Shigella dysentriae. Ekstrak Kunyit yang digunakan memiliki konsentrasi 15\% , 30\%, 50\%, 75\%, 100\%. Kontrol 
positif digunakan Amoksilin dan Chlorampheniocol. Hasil pengamatan menunjukkan ekstrak Kunyit memiliki daya hambat terhadap pertumbuhan bakteri Bacillus sp dan Shigella dysentriae.

Berdasarkan dari tiga penelitian sebelumnya didapat ada pengaruh yang efektif pada setiap perlakuannya semakin konsentrasi naik maka akan menurunkan daya hinggap lalat pada penelitian Rosnawati (1998) dan Fardaniyah (2007) serta dapat menghambat pertumbuhan bakteri Bacillus sp dan Shigella dysentriae pada penelitian Warnaini (2007), tetapi berbeda dengan hasil penelitian ini pada berbagai jenis dan konsentrasi untuk menghambat hinggapnya lalat pada ikan asin dari jam ke 1 sampai jam ke 6. Lama efek repellent terhadap berbagai jenis dan konsentrasi untuk menghambat hinggapnya lalat pada ikan asin sebenarnya ada pengaruh yang signifikan tetapi pada tiap jamnya berbagai jenis dan konsentrasi untuk menghambat hinggapnya lalat pada ikan asin mengalami fluktuasi pada efek repellent pada tiap jamnya. Hal tersebut dapat terjadi karena keterbatasan dari penelitian ini. Adapun solusi yang dapat dilakukan dalam melakukan penelitian selanjutnya di antaranya sebagai berikut :

Pembuatan ekstrak Kencur (Kaempferia galanga L.), Serai Wangi (Cymbopogon nardus L.) dan Kunyit (Curcuma longa L.) sebaiknya pelarut yang digunakan adalah etanol, karena etanol sebagai pelarut dapat memperbaiki atau mempertahankan sifat dan karakteristik bahan terlarut serta mampu mengendapkan zat-zat yang terkandung dalam bahan. Etanol banyak digunakan sebagai pelarut karena etanol relative aman digunakan untuk bahan-bahan kimia yang ditujukan untuk konsumsi dan kegunaan manusia. Etanol dipilih sebagai pelarut karena etanol merupakan pelarut yang bersifat polar, yang artinya dapat melarutkan senyawa polar dan etanol bisa bercampur dengan air yang juga bersifat polar. Sifat yang penting adalah polaritas dan gugus polar suatu senyawa. Pada prinsipnya suatu bahan akan mudah larut dalam pelarut yang sama polaritasnya sehingga akan mempengaruhi sifat fisikokimia ekstrasi yang dihasilkan (Sudarmadji, 1997 dalam Puspita, 2009).

Metode pembuatan ekstrak Kencur (Kaempferia galanga L.), Serai Wangi (Cymbopogon nardus L.) dan Kunyit (Curcuma longa L.) sebaiknya menggunakan metode ekstrasi sokletasi dengan prinsip penyairan secara terus menerus sehingga penyairan lebih sempurna dengan memakai pelarut yang relative sedikit. Jika penyairan selesai maka pelarutannya diuapkan dan sisanya adalah zat yang tersari. Biasanya pelarut yang digunakan adalah pelarut yang mudah menguap atau mempunyai titik didih yang rendah. Adapun keunggulan ekstrasi dengan cara sokletasi antara lain :

1. Proses ekstraksi simplisia sempurna sehingga dalam penggunaannya mempunyai daya pengaruh yang tinggi.

2. Pelarut yang digunakan sedikit.

3. Proses isolasi lebih cepat.
Tanaman Kencur (Kaempferia galanga L.), Serai Wangi (Cymbopogon nardus L.) dan Kunyit (Curcuma longa L.) merupakan salah satu tanamantanaman rempah penghasil minyak atsiri yang banyak mengandung geraniol. Tanaman Kencur (Kaempferia galanga L.), Serai Wangi (Cymbopogon nardus L.) dan Kunyit (Curcuma longa L.) dapat dijadikan insektisida alternatif yang aman bagi lingkungan yang berasal dari tanaman, karena Tanaman Kencur (Kaempferia galanga L.), Serai Wangi (Cymbopogon nardus L.) dan Kunyit (Curcuma longa L.) memproduksi minyak atsiri yang aromanya tidak disukai serangga, yang salah satunya berfungsi sebagai pengusir lalat.

Menurut uji statistik pada tabel deskriptif ada pengaruh pemberian ekstrak tanaman Kencur (Kaempferia galanga L.), Serai Wangi (Cymbopogon nardus L.) dan Kunyit (Curcuma longa L.). Penurunan jumlah larva disebabkan oleh bau minyak tanaman Kencur (Kaempferia galanga L.), Serai Wangi (Cymbopogon nardus L.) dan Kunyit (Curcuma longa L.) yang khas dan cukup keras mampu menurunkan jumlah lalat yang hinggap, yang kemudian akan meletakkan telur, dan berkembang menjadi larva. Salah satu rangsangan sensoris yang mengakibatkan ketertarikan lalat untuk hinggap pada suatu media adalah rangsangan bau selain rangsangan visual, suhu dan kelembaban. Minyak atsiri yang merupakan kandungan tanaman Kencur (Kaempferia galanga L.), Serai Wangi (Cymbopogon nardus L.) dan Kunyit (Curcuma longa L.) tampaknya bekerja memblokir syaraf sensoris lalat sehingga menghindarkan lalat dewasa untuk hinggap yang mengakibatkan menurunkan jumlah infestasi larva lalat pada media ikan asin. Tanaman rempah Kencur (Kaempferia galanga L.), Serai Wangi (Cymbopogon nardus L.) dan Kunyit (Curcuma longa L.) lebih mudah didapat, murah dan dapat digunakan sebagai insektisida nabati untuk mencegah miasis pada pengolahan ikan asin, dan tidak menimbulkan efek yang merugikan. Sehingga minyak atsiri ini lebih aman, dan ekonomis untuk digunakan sebagai insektisida nabati pada pengolahan makanan (Jenings 271987 dalam Fardaniyah, 2007). Berikut pengaruh jenis dan dosis ekstrak pada perlakuan ikan asin :

\section{Pengaruh Dosisi Ekstrak Kencur (Kaempferia galanga L.) pada Ikan Asin}

Menurut deskripsi uji statistik anova faktoral, konsentrasi ekstrak Kencur 3\%, 6\%, 12\%, dan 24\% pada perlakuan ikan asin memiliki pengaruh untuk dapat menolak lalat. Pada dosis $3 \%$ yaitu rata-rata daya proteksi sebesar $64,2222 \%, 6 \%$ yaitu rata-rata daya proteksi sebesar 73,3532\%, 12\% yaitu rata-rata daya proteksi sebesar $62,6777 \%$, dan $24 \%$ yaitu ratarata daya proteksi sebesar 70,1131\%. Hal tersebut dapat dikatakan ekstrak Kencur memiliki pengaruh karena dari hasil deskiptif statistik didapatkan ratarata daya proteksi yang tinggi pengaruhnya pada perlakuan daya tolak lalat pada ikan asin pada ekstrak 
Kencur dengan dosis 6\% yang mempunyai rata-rata 73,3532\%.

Pengaruh terhadap lalat dengan adanya perlakuan berupa dosis ekstrak Kencur yang dioleskan pada ikan asin dengan rata - rata daya proteksi paling tinggi pada dosis 6\% (73,3532\%), dan paling rendah $12 \%(62,6777 \%)$.

\section{Pengaruh Dosis Ekstrak Serai Wangi (Cymbopogon nardus L.) pada Ikan Asin}

Menurut deskripsi uji statistik anova faktoral, dosis ekstrak Serai Wangi 3\%, 6\%, 12\%, dan 24\% pada perlakuan ikan asin memiliki pengaruh untuk dapat menolak lalat. Pada dosis 3\% yaitu rata-rata daya proteksi sebesar 48,598\%, $6 \%$ yaitu rata-rata daya proteksi sebesar $61,7882 \%, 12 \%$ yaitu rata-rata daya proteksi sebesar 50,1235\%, dan $24 \%$ yaitu ratarata daya proteksi sebesar 56,5194\%. Hal tersebut dapat dikatakan ekstrak Serai Wangi memiliki pengaruh karena dari hasil deskiptif statistik didapatkan rata-rata daya proteksi yang tinggi pengaruhnya pada perlakuan daya tolak lalat pada ikan asin pada ekstrak Serai Wangi dengan dosis $12 \%$ yang mempunyai rata-rata $61,7882 \%$.

Pengaruh terhadap lalat dengan adanya perlakuan berupa dosis ekstrak Serai Wangi yang dioleskan pada ikan asin dengan rata - rata daya proteksi paling tinggi pada dosis 12\% (61,7882\%), dan paling rendah 3\% (48,598\%).

\section{Pengaruh Dosis Ekstrak Kunyit (Curcuma longa L.) pada Ikan Asin}

Menurut deskripsi uji statistik anova faktoral, dosis ekstrak Kunyit 3\%, 6\%, 12\%, dan 24\% pada perlakuan ikan asin memiliki pengaruh untuk dapat menolak lalat. Pada dosis 3\% yaitu rata-rata daya proteksi sebesar 65,3517\%, $6 \%$ yaitu rata-rata daya proteksi sebesar 44,0940\%, 12\% yaitu rata-rata daya proteksi sebesar 50,1235\%, dan 24\% yaitu rata-rata daya proteksi sebesar 56,5194\%. Hal tersebut dapat dikatakan ekstrak Kunyit memiliki pengaruh karena dari hasil deskiptif statistik didapatkan rata-rata daya proteksi yang tinggi pengaruhnya pada perlakuan daya tolak lalat pada ikan asin pada ekstrak Kunyit dengan dosis $3 \%$ yang mempunyai rata-rata 65,3517\%.

Pengaruh terhadap lalat dengan adanya perlakuan berupa dosis ekstrak Kunyit yang dioleskan pada ikan asin dengan rata - rata daya proteksi paling tinggi pada dosis 3\% (65,3517\%), dan paling rendah 6\% (44,0940\%).

Berdasarkan dari keseluruhan pengaruh jenis dan dosis ekstrak Kencur (Kaempferia galanga L.), Serai Wangi (Cymbopogon nardus L) dan Kunyit (Curcuma longa L.) terhadap ikan asin yang digunakan sebagai daya tolak lalat, hasil deskiptif statistik didapatkan rata-rata daya proteksi yang tinggi pengaruhnya pada perlakuan daya tolak lalat pada ikan asin pada ekstrak Kencur dengan dosis 6\% yang mempunyai rata-rata 73,3532\%.
Menganalisis Efektifitas Berbagai Jenis dan Dosis Ekstrak Kencur (Kaempferia galanga L.), Serai Wangi (Cymbopogon nardus $L$ ) dan Kunyit (Curcuma longa L.) pada Ikan Asin

Hasil uji statistik menunjukkan bahwa terdapat perbedaan pada masing - masing jenis dan dosis yaitu jenis Kencur dengan Serai Wangi Kunyit dan serai dengan Kencur, Kunyit yang signifikan. Pada dosis $3 \%$ dengan $6 \%, 12 \%$, dan $24 \%$ dan dosis $12 \%$ dengan dosis $3 \%$, $6 \%$, dan $24 \%$ yang signifikan. Jika yang dibaca nilai $\mathrm{F}$ hitung, maka perlu dibandingkan dengan nilai tabel, jika lebih besar, maka Ho ditolak, bisa juga dilihat pada nilai p (sig) jika $<\alpha=5 \%$ / $0,05,(0,000<0,05)$ maka Ho ditolak artinya maka dilanjutkan untuk menentukan diantara perlakuan mana yang paling baik untuk menolak lalat, maka pembacaan terhadap post hock dilanjutkan.

Hasil perbandingan menunjukkan terdapat jenis dan dosis yang signifikan, maka diambil yang paling baik yaitu selisih paling besar dengan reference group yang sama, pada jenis Kencur selisih paling besar dengan jenis Kunyit, karena selisih rata - rata (mean defference) 13,569 dan pada dosis 6\%, selisih paling besar dengan dosis $12 \%$ karena selisih rata rata (mean defference) 5,437, maka dosis yang paling baik untuk menolak lalat adalah dosis 6\% dari dosis yang lain, dan pada dosis tersebut dapat dikatakan paling berpengaruh karena lalat yang tidak hinggap mencapai $90 \%$ pada jam ke 5 dengan nilai mean 97.222.

Lama Waktu Kontak Berbagai Jenis dan Dosis Ekstrak Kencur (Kaempferia galanga L.), Serai Wangi (Cymbopogon nardus L.) dan Kunyit (Curcuma longa L.) pada Ikan Asin

Berdasarkan uji statistik anova faktorial dari hasil uji persyaratan yaitu distribusi data apakah memenuhi syarat atau tidak, maka dilihat dari uji homogenitas, jika nilai $\mathrm{p}<0,05$, maka data heterogen dan memenuhi syarat. Hasil analisis nilai $p=0,320>\alpha$ $(0,05)$ berarti data analisis jenis repellent terhadap waktu heterogen dan memenuhi syarat distribusi data homogen, dengan demikian analisis dapat dilanjutkan. Hasil analisis nilai sig $\mathrm{p}=0,00<\alpha(0,05)$ yang berarti waktu berpengaruh terhadap efek repellent dan berinteraksi terhadap variabel lain dengan nilai sig $\mathrm{p}=0,001<\alpha(0,05)$ yang berpengaruh terhadap efek repellent tetapi hal tersebut dapat dilihat pada hasil perlakuan tiap jamnya, karena hasil menunjukkan data fluktuasi pada tiap jenis dan dosis repellent.

\section{SIMPULAN DAN SARAN}

\section{Simpulan}

1. Daya proteksi repellent pada masing - masing jenis dan dosis ekstrak pada ikan asin selama 6 jam yaitu

a. Ekstrak Kencur (Kaempferia galanga L.) dengan dosis $3 \%$ rata-rata $65,4 \%$, dosis $6 \%$ 
rata-rata $75,4 \%$, dosis $12 \%$ rata-rata $65,6 \%$, dan dosis $24 \%$ rata-rata $71,1 \% \%$.

b. Ekstrak Serai Wangi (Cymbopogon nardus $L$ ) dengan dosis 3 rata-rata $53,2 \%$, dosis $6 \%$ rata-rata $66,6 \%$, dosis $12 \%$ rata-rata $55,2 \%$, dan dosis $24 \%$ rata-rata $67,8 \%$.

c. Ekstrak Kunyit (Curcuma longa L.) dengan dosis $3 \%$ rata-rata $64,4 \%$, dosis $6 \%$ rata-rata $44,3 \%$, dosis $12 \%$ rata-rata $61,9 \%$, dan dosis $24 \%$ rata-rata $69,8 \%$.

2. Ada pengaruh berbagai jenis dan dosis Ekstrak Kencur (Kaempferia galanga L.), Serai Wangi (Cymbopogon nardus L) dan Kunyit (Curcuma longa L.), pada dosis 3\%, 6\%, 12\% dan 24\% terhadap hinggapnya lalat pada ikan asin.

a. Ekstrak Kencur (Kaempferia galanga L.), dengan konsentrasi 3\% sebanyak 64,2222\%, $6 \%$ sebanyak $73,3532 \%$, $12 \%$ sebanyak 62.6777 dan 24\% sebanyak 70,1131\%.

b. Ekstrak Serai Wangi (Cymbopogon nardus L.) dengan konsentrasi 3\% sebanyak 48,5981\%, 6\% sebanyak 61,7882\%, $12 \%$ sebanyak 50,1235\% dan 24\% sebanyak 56,5194\%.

c. Ekstrak Kunyit (Curcuma longa L.) dengan konsentrasi 3\% sebanyak 65,3517\%, 6\% sebanyak 44,0940\%, $12 \%$ sebanyak 50,1235\% dan 24\% sebanyak 56,5194\%.

3. Menurut Departemen Pertanian dalam Metode Standar Pengujian Efikasi Pestisida tahun 1995 yaitu repellent dianggap efektif apabila hingga jam ke-6 daya proteksinya masih diatas $90 \%$, dengan demikian tidak ada jenis dan dosis repellent yang paling efektif untuk mengurangi hinggapnya lalat pada ikan asin.

\section{Saran}

1. Bagi para pengusaha ikan asin diharapkan untuk dapat menjaga kebersihan lingkungan di sekitar tempat pengolahan sebelum dan setelah melakukan pengolahan ikan asin dengan menggunakan bahan kimia untuk membersihkan bau olahan ikan asin sebab keberadaan serangga khususnya lalat sangat dipengaruhi oleh kebersihan lingkungan terutama pada kebersihan badan air.

2. Ditujukan kepada masyarakat pasar agar menjaga kebersihan lingkungan pasar dengan tidak membuang sampah sembarangan baik sampah organic dan anorganik sehingga tidak menimbulkan adanya keberadaan lalat yang lebih banyak.

3. Peneliti lain dapat melakukan penelitian sejenis dengan menggunakan metode ekstrasi sokletasi dan menggunakan pelarut etonal atau metanol.

\section{DAFTAR PUSTAKA}

Afrensi, DO., 2007, Pengaruh Minyak Atsiri Kemangi (Ocimumbasilicum forma citratum
Back) Terhadap Infestasi Larva LalatHijau (Chrysomya megacephala) Pada Ikan Mas (Cyprinuscarpio), Skripsi Fakultas Kedokteran Hewan, Institut Pertanian Bogor

Afriyanto, E \&Liviawaty, E., 1991, Pengawetan dan Pengolahan Ikan, Kanisius, Yogyakarta

Afniaty I,, 2006. Substitusi Tepung Kunyit (Curcuma domestica Val.) dalamPakan Jangkrik Kalung (Gryllusbimaculatus) pada Periode Bertelur, Skripsi Fakultas Peternakan, Institut Pertanian Bogor

Aisyah, I., 1997. Pengaruh Tepung Rimpang Kunyit (Curcuma Domestica Val) terhadap Palatabilitas Umpandan Reproduksi Mencit Putih (Musmusculus).Skripsi. Fakultas Pertanian. Institut Pertanian Bogor, Bogor.

Amir, M., Bariyahdan W. A. Baringbing., 1976.Pengaruh Kimia Genus Curcuma terhadap Fertilitas Lalat Rumah. Pemberitaan LPTI 10: 31-36.

Ariyani, F, Haryati, S, Wahyuni, M \&Wisudo, SH., 2007, Penggunaan Ekstrak Bahan Alami untuk Menghambat Infestasi Lalat selama Penjemuran Ikan Jambal asin, Jurnal Pascapanen dan Bioteknologi Kelautan dan Perikanan Vol.2 No.2

Emmy, LS., 1995, Mewaspadai Bahaya Pestisida, Yayasan Lembaga Konsumen Indonesia, Jakarta

Fardaniyah, F 2007, Pengaruh Pemberian Minyak Serai Wangi (Cymbopogon nardus [L] Rendle) terhadapInfestasiLalatHijau (Chrysomya megacephala [Fab]), Skripsi Fakultas Kedokteran Hewan, Institut Pertanian Bogor, http://repository.ipb.ac.id/bitstream/handle/1 23456-

789/23167/B08ff_abstract.pdf?sequence=2. Diakses pada tanggal|24-01-2016, $\rceil 10: 15$ wib

Hanafiah, KA., 2008, Rancangan Percobaan Teori \& Aplikasi Edisi Revisi, PT. Raja Grafindo Persada, Jakarta

Haryati, S., 2013, Optimalisasi Penggunaan Bawang Putih sebagai Pengawet Alami dalam Pengolahan IkanJambal Roti, Tesis, Sekolah Pasca Sarjana IPB Heruwati, ES 2002, Pengolahan Ikan SecaraTradisional: Prospek dan Peluang Pengembangan, Jurnal Litbang Pertanian 
Heruwati, ES., 2002, Pengolahan Ikan Secara Tradisional: Prospek dan Peluang Pengembangan, Jurnal Litbang Pertanian

Heyne, K., 1987. Tumbuhan Berguna Indonesia. Yayasan Sarana Wana Jaya. Jakarta

Indrasih, Minar, dkk., 2015, Pemanfaatan Ekstrak Daun Cengkeh (Syzigium aromaticum) sebagai Repellent Nabati dalam Mengurangi Jumlah Lalat yang Hinggap Selama Proses Penjemuran Ikan Asin, Skripsi Fakultas Kesehatan Masyarakat, Universitas Sumatera Utara, Medanhttp://prosiding.lppm.unisba.ac.id/index.php/Sains/arti cle/download/725/pdf. Diakses pada tanggal 22-11-2015, 20.30 wib

Intania, A., 2006. Substitusi Tepung Kunyit (Curcuma domestica Val.) dalam Pakan Jangkrik Kalung (Gryllusdi maculatus) pada Periode Bertelur. Skripsi Fakultas Peternakan Institut Pertanian Bogor

Kardinan, A., 2007, Daya Tolak Ekstrak Tanaman Rosemary (Rosmarinus officinalis) terhadap Lalat Rumah (Musca domestica), BalaiPenelitian Tanaman Obat dan Aromatik

Lutony, TL \& Rahmayati., Y 2002, Produksi dan Perdagangan Minyak Asiri, Penebar Swadaya, Jakarta

Muchlis, A.N, R. Sofjan., 1978. Masalah Analisa Total Geraniol pada Minyak Serai Wangi. Pemberitaan LPTI No: 28.LPTI. Bogor

Puspita, M., 2009, Studi Efektivitas Berbagai Konsentrasi Ekstrak Serai Wangi (Cymbopogon Nardus) Dalam Hand And Body Lotion Sebagai Repellent Nyamuk Aedes Aegypti di Banjarnegara Tahun 2009, Jurusan DIII Kesehatan Lingkungan, Poltekkes Kemenkes Semarang

Naria, E., 1994, Tinjauan Efek Residu Pestisida dalam Bahan Pangan yang Dikonsumsi Masyarakat, Fakultas Kesehatan Masyarakat, Universitas Sumatera Utara
Nuryoto, Jayan udin\& Hartono., R 2011, Karakterisasi Minyak Atsiri dari Limbah Daun Cengkeh, Prosiding Seminar Nasional Teknik Kimia “Kejuangan”, Yogyakarta

Rosnawati, D., 1998, Penggunaan Ekstrak Kencur sebagai Insektisida Nabati dalam Pengendalian Serangan Lalat pada Pengolahan Ikan Asin , Skripsi, Fakultas Teknologi Pertanian , Institut Pertanian Bogor, http://repository.ipbac.id/bitstream/handle/1 23456789/40176/F98dro.pdf?sequence=1\&i sAllowed=y. Diakses pada tanggal [24-01[2016, \$9:25 wib

Santjaka, A., 2008, Statistik untuk Penelitian Kesehatan Vol 2, Jurusan Kesehatan Lingkungan, Politeknik Kemenkes Semarang, Purwokerto

Sibagariang, E., 2006, Analisa Kandungan Insektisida pada Ikan Asin di Pasar yang ada di Kota Medan, Skripsi, Fakultas Kesehatan Masyarakat, Universitas Sumatera Utara, Medan

Sujoto, H., 2000, Petunjuk Teknis tentang Pemberantasan Lalat, Perum AKL Baturaden Purwokerto

Warnaini, C., 2010, Uji Efektivitas Ekstrak Kunyit sebagai Anti bakteri terhadap Pertumbuhan Bakteri Bacillus sp. Dan Shigella dysentriae Secara In Vitro, Fakultas Teknologi Pertanian, Institut Pertanian Bogor, http://journal.ipb.ac.id/index.php/jurnaltin/ar ticle/view/4301/2914. Diakses pada tanggal 27-01-2016, 15.15 wib

Warta, P., 2013. Penelitian dan Pengembangan Tanaman Industri, Vol 9 No 2, Yogyakarta, http://perkebunan.litbang.pertanian.go.id/wp -content/uploads/2014/02/Perkebunan_KhasiatKunyit.p df. Diakses pada tanggal 27-01- 2016, 14:48 wib 